\title{
Implementasi Model Kepemimpinan Demokratis Kepala Sekolah Dalam Meningkatkan Disiplin Guru Mengajar
}

\author{
YULIAN HEROSITA \\ Sekolah Dasar Negeri 023 Pandau Jaya \\ Jln. AR. Rahim IV No. 1 Siak Hulu, Kampar \\ E-mail : yuliaherosita@yahoo.com
}

\begin{abstract}
Labor discipline problems teachers provide learning to students is a phenomenon that needs to be addressed. Through the democratic leadership of headmaster attitude is presumably related to discipline the teacher. Using action research methods were implemented school at SDN 023 samples Pandau Jaya and teachers with the implementation of democratic kepemimponan models and descriptive analysis, the obtained results of the research granting school leadership teacher work can improve work discipline teachers in teaching in schools. The data obtained show that once held measuring the level of work discipline teachers through school leadership to work more efficiency, effectiveness, fairness and responsiveness to the application of these cycles affect the teachers' work. This suggests the provision of school leadership work can improve work discipline teachers in teaching in elementary school N 023 Pandau Jaya.
\end{abstract}

Keywords: Democratic leadership model, Discipline Teacher

Guru adalah salah satu komponen manusiawi dalam proses belajar mengajar, yang ikut berperan dalam usaha pembentukan sumber daya manusia yang potensial di bidang pembangunan. Oleh karena itu guru yang merupakan salah satu unsur di bidang kependidikan harus berperan secara aktif dan menempatkan kedudukannya sebagai tenaga profesional sesuai dengan tuntutan masyarakat yang semakin berkembang. Dalam hal ini guru tidak semata-mata sebagai pengajar yang melakukan transfer ilmu pengetahuan, tetapi juga sebagai pendidik yang melakukan transfer nilai-nilai sekaligus sebagai pembimbing yang memberikan pengarahan dan menuntun siswa dalam belajar (Rachmawati, 2013)

Kinerja guru selalu menjadi perhatian karena merupakan faktor penentu dalam meningkatkan prestasi belajar. Ia sangat berperan dalam meningkatkan kualitas pendidikan di sekolah. Rendahnya kinerja guru akan berpengaruh terhadap kualitas kelulusan siswa yang pada akhirnya berpengaruh pula terhadap pencapaian tujuan pendidikan. kepemimpinan visi kepala sekolah sangat baik, kepribadian, pemahaman misi, dan kemampuan berkomunikasi baik. Akan tetapi dalam hal pemahaman terhadap kondisi guru dan keberanian dalam mengambil keputusan 53\% responden menilai kurang baik. (Djatmiko, 2006)

Menurut Aan Komarian pimpinan di sekolah mempunyai kemampuan untuk mempengaruhi orang lain agar ia mau mengikuti tujuan sekolah atau organisasi. Mempengaruhi orang lain dimaksudkan untuk mengubah tingkah laku orang atau bawahan agar menyatukan tindakannya ke arah sasaran yang hendak dicapai. Adapun kepemimpinan pendidikan saat ini adalah kepemimpinan yang didasarkan pada jati diri bangsa yang hakiki yang bersumber dari nilai?nilai budaya dan agama, serta mampu mengantisipasi perubahan? perubahan yang terjadi dalam dunia pendidikan khususnya dam umumnya atas kemajuan? kemajuan yang diraih di luar system sekolah. (Djatmiko, 2006)

Kinerja guru kaitannya dengan disiplin menurut Hasibuan disiplin kerja adalah sangat penting dalam suatu organisasi. Dengan disiplin kerja para pegawai dapat melaksanakan tugas- 
tugasnya guna mewujudkan tujuan organisasi tersebut. Disiplin kerja mengatur seorang pegawai untuk mentaati segala norma, kaidah dan peraturan yang berlaku dalam organisasi. Tujuan disiplin kerja ini dalam rangka memperlancar seorang pegawai dalam melaksanakan pekerjaannya agar pencapaian tujuan organisasi tepat waktu, tepat sasaran serta efektif dan efesien. Disiplin kerja adalah kesadaran dan kesediaan sese- orang menaati semua peraturan perusa- haan dan norma-norma sosial yang berlaku.(Arief Chaidir Abdillah, 2011)

Salah satu faktor dari manajemen pendidikan yang penting tetapi masih kurang tersentuh dalam program pembangunan pendidikan adalah kepemimpinan Kepala Sekolah. Sebesar apapun input perse- kolahan ditambah atau diperbaiki, outputnya tetap tidak akan optimal, apabila faktor kepemimpinan $\mathrm{Ke}$ pala Sekolah yang merupakan aspek yang sangat strategis dalam proses belajar mengajar, tidak dibe- rikan perhatian yang memadai. Hal itu disebabkan Kepala Sekolah adalah pengelola terdepan yang memutuskan dapat tidaknya setiap input berproses dan berinteraksi secara positip dalam sistem belajar mengajar. Kepala Sekolah memiliki peranan yang dominan untuk mendorong upaya inovasi baik yang berasal dari luar maupun yang timbul dari dalam sekolahnya. (Ekosiswoyo, 2007)

Indonesia merupakan implementasi dari empat pilar pendidikan yang dicanangkan UNESCO. Empat pilar ini merupakan visi pendidikan dimasa sekarang dan masa depan yang perlu dikembangkan oleh lembaga pendidikan formal dimanapun. Keempat pilar tersebut yaitu: (1) learning to know (belajar untuk mengetahui), (2) learning to do (belajar untuk melakukan sesuatu), (3) learning to be (belajar untuk menjadi seseorang) dan (4) learning to live together (belajar untuk menjalani kehidupan bersama). (eko triono, 2013)

Fenomena mengenai guru kurang disiplin yang terjadi di SDN 023 Pandau Jurnal Daya Saing
Jaya menjadikan perhatian kepala sekolah selama ini. Namun apabila dilihat dari sisi kepemimpinan kepala sekolah dalam mengelola sekolahnya, apakah ada kaitannya dengan model kepemimpinan kepala sekolah.

Menurut bahwa Aminah disiplin kerja guru dipengaruhi oleh kepemimpinan kepala sekolah sebesar $52 \%$. Karena antara kepemimpinan kepala sekolah dengan disiplin kerja guru memiliki keterkaitan atau hubungan yang kuat. Sedangkan sisanya $48 \%$ dipengaruhi oleh faktor-faktor lain. Pembagian disiplin kerja tersebut dilihat dari bagaimana cara kepala sekolah dalam memberikan perintah-perintah kepada guru agar guru dapat melaksanakan perintahnya tersebut, namun cara tersebut berbeda-beda. Pada konsep otoritarian kepala sekolah menuntut ketaatan yang penuh kepada guru-guru agar menjalankan perintahnya dengan baik. Pada konsep permissive, kepala sekolah memberikan kebebasan kepada guru untuk melakukan apa saja yang ingin dilakukan oleh guru di kelas maupun di sekolah selama perbuatan tersebut dianggap dapat meningkatkan kemajuan sekolah, tentunya dalam konsep ini akan menyebabkan guru tidak disiplin karena bekerja sesuai dengan kemauannya sendiri yang menyebabkan banyak tugas yang tidak terselesaikan. Pada konsep kebebasan yang terkendali, guru diberi kebebasan dalam menjalankan tugasnya tetapi ia harus bertanggung jawab terhadap tugas yang telah dilakukannya tersebut. (Siti Aminah, 2010)

\section{METODE}

Metode yang digunakan dalam penelitian ini adalah metode penelitian tindakan sekolah, PTS bertujuan untuk mencari pemecahan permasalahan nyata yang terjadi di sekolah-sekolah, sekaligus mencari jawaban ilmiah bagaimana masalah-masalah tersebut bisa dipecahkan melalui suatu tindakan perbaikan. Tindakan yang dilakukan dalam penelitian ini adalah

$$
\text { p.ISSN: } 2407-800 X \quad \text { e.ISSN: 2541-4356 }
$$


memberikan kepemimpinan kepala sekolah pada akhir bulan, yakni dengan tahapan pertama hanya dalam bentuk memberikan kepemimpinan kepala sekolah dan tahapan kedua yaitu dengan memberikan pengumuman seluruh guru, dan tahapan selanjutnya dengan mengumumkan guru guru dan langsung diberikan pengarahan. Diharapkan dengan pemberian tindakan ini akan terjadi perubahan atau peningkatan disiplin kerja guru dalam mengajar di sekolah.

Karena keterbatasan waktu, penelitian tindakan sekolah ini hanya dilaksanakan sebanyak 3 siklus masing-masing siklus dilaksanakan selama 1 bulan. Teknik pengumpulan data dari penelitian tindakan sekolah ini adalah melalui data kualitatif yang diperoleh dari observasi, pengamatan, maupun wawancara. Instrumen penelitian yang digunakan dalam penelitian tindakan sekolah ini antara lain adalah: Skala penilaian; lembar pengamatan dan angket. Analisa data yang digunakan dalam penelitian ini adalah analisa data kualitatif yang bersumber dari data primer maupun empiris.

\section{HASIL}

Penelitian ini dilaksanakan dalam tiga siklus. Hal ini dikarenakan keterbatasan waktu yang tersedia, serta dengan tiga siklus sudah penulis anggap cukup untuk peningkatan disiplin kerja dalam proses pembelajaran.

Melalui penerapan langkah tindakan sebagai berikut:

Siklus 1 terdiri beberapa tahapan, yaitu: 1) Perencanaan; 2) Pelaksanaan; 3) Pengamatan dan 4) Refleksi. Dari sisi perencanaan, perencanaan adalah langkah awal yang dilakukan oleh penulis saat akan memulai tindakan. Agar perencanaan mudah dipahami dan dilaksanakan oleh penulis yang akan melakukan tindakan, maka penulis akan membuat rencana tindakan sebagai berikut: Merumuskan masalah yang akan dicari solusinya. Dalam penelitian ini masalah yang akan dicari solusinya adalah: masih rendahnya disiplin kerja guru dalam mengajar; merumuskan tujuan penyelesaian masalah/tujuan menghadapi tantangan/ tujuan melakukan inovasi/tindakan.

Dalam penelitian ini penulis mengambil rencana untuk melakukan tindakan pemberian tindakan dalam tindak ketidakdisiplinan di sekolah yang dilakukan guru; merumuskan indikator keberhasilan pemberian penilaian terhadap kedisiplinan guru. Indikator keberhasilan penerapan tindakan ini penulis tetapkan dengan skala likert; merumuskan langkah-langkah kegiatan penyelesaian masalah/kegiatan menghadapi tantangan/kegiatan melakukan tindakan. Langkah-langkah yang diambil penulis dalam melakukan tindakan antara lain adalah melakukan sosialisasi kepada para guru mengenai penelitian yang akan dilakukan, serta menyampaikan tujuan dari penerapan tindakan yang dilakukan oleh penulis. Kepada para guru disampaikan mengenai pemberian penilaian kepada prestasi kerja guru yang akan diterapkan pada penelitian ini.

Pada siklus ini, guru akan dinilai bagaimana hasil disiplin kerjanya selama 1 bulan. Mengidentifikasi warga sekolah dan atau pihak terkait lainnya yang terlibat dalam penyelesaian masalah/menghadapi tantangan/melakukan tindakan. Penulis melakukan identifikasi siapa saja yang dilibatkan dalam penelitian ini. Pihak-pihak yang dilibatkan dalam penelitian ini adalah: guru dan kepala sekolah. Mengidentifikasi metode pengumpulan data yang akan digunakan.

Metode pengumpulan data yang diambil oleh penulis merupakan data kualitatif melalui observasi, pengamatan serta wawancara kepada guru mengenai disiplin kerja dalam mengajar. Penyusunan instrumen pengamatan dan evaluasi. Dalam pengambilan data, penulis menggunakan instrumen berupa lembar observasi/ pengamatan. Skala penilaian serta angket yang disebarkan kepada guru, untuk mengetahui kepemimpinan kepala sekolah kerja dari guru dalam mengajar. Mengidentifikasi fasilitas yang diperlukan. Fasilitas atau alat bantu yang digunakan

p.ISSN: $2407-800 X \quad$ e.ISSN: 2541-4356 
dalam penelitian ini antara lain: kertas (lembar pengamatan) dan alat tulis berupa balpoint serta kalender.

Pelaksanaan penelitian tindakan sekolah ini dilaksanakan melalui beberapa kegiatan, antara lain: Menyebarkan lembar pengamatan kepada setiap guru sesuai dengan banyaknya guru di SD N 023 Pandau Jaya. Dalam lembar pengamatan itu, telah dibuat pertanyaan mengenai baik atau tidak baiknya disiplin guru dalam mengajar dengan memberikan tanda contreng pada pilihan jawaban yang dianggap paling sesuai. Berkoordinasi dengan kepala sekolah yang akan memberikan kepemimpinan kepala sekolah kerja guru dalam mengajar. Setelah selesai mengumpulkan data, dilakukan rekapitulasi data penelitian. Kegiatan tersebut dilakukan terus kepada setiap guru dalam tahapan kepemimpinan kepala sekolah.

Pengamatan atau observasi dilakukan oleh peneliti, dengan menggunakan lembar observasi selama 1 bulan (satu siklus), untuk semua guru. Selama pengamatan peneliti dibantu atau berkolaborasi dengan kepala sekolah. Pengamatan oleh peneliti meliputi: Seorang guru melakukan kesalahan, maka guru harus konsekuen terhadap aturan pelanggaran. Tidak dilakukan secara konsekuen berarti guru tersebut melecehkan peraturan yang sudah ditetapkan. Kedua hal diatas akan berakibat pemutusan hubungan kerja dan pegawai harus menerima hukuman tersebut.

Perubanan terhadap kedisiplinan guru pasca diberikannya terapan kepemimpinan model demokratis sebagai berikut:

Gambar 1: Perubanan terhadap kedisiplinan guru pasca diberikannya terapan kepemimpinan model demokratis

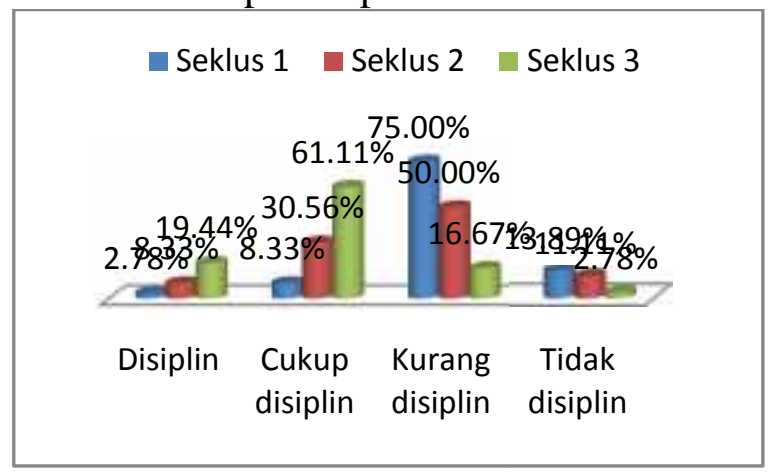

Jurnal Daya Saing

\section{PEMBAHASAN}

Pemberian kepemimpinan kepala sekolah kerja guru dapat meningkatkan disiplin kerja guru dalam mengajar di sekolah. Data yang diperoleh menunjukkan bahwa setelah diadakan mengukur tingkat disiplin kerja guru melalui kepemimpinan kepala sekolah kerja yang lebih efisiensi, efektif, keadilan dan daya tanggap dengan penerapan siklus ini berpengaruh kepada kerja guru. Hal ini menunjukkan pemberian kepemimpinan kepala sekolah kerja dapat meningkatkan disiplin kerja guru dalam mengajar di SD N 023 Pandau Jaya.

Pelaksanaan tindakan pada semua siklus maka diadakan refleksi mengenai kelemahan atau kekurangan dari pelaksanaan tindakan pada siklus kedua tersebut. Refleksi dilaksanakan bersamasama berkolaborator untuk menentukan tindakan perbaikan pada siklus berikutnya. Dari hasil observasi dan data yang diperoleh, peneliti mengambil kesimpulan bahwa tindakan yang dilaksanakan pada siklus ketiga disiplin kerja guru dinyatakan sudah baik, karena kepemimpinan kepala sekolah yang diberikan semakin menurun.

Hal ini sebagaimana dijelaskan oleh Fleet bahwa seorang pemimpin memiliki paling tidak lima power, yaitu (a) reward power, yaitu kewibawaan yang menyebabkan bawahan atau orang lain melak- sanakan tugas tertentu dengan harapan agar mem- peroleh hadiah yang diberikan, (b) coersive power, yaitu kewibawaan yang mendorong bawahan atau orang lain berbuat sesuatu dengan motivasi agar terhindar dari hukuman yang diberikan oleh pemim- pin, (c) legitimate power, yaitu kewibawaan yang mendorong bawahan atau orang lain mengerjakan sesuatu karena memiliki kewenangan sehingga orang lain mempunyai kewajiban mematuhinya, (d) expert power, yaitu bawahan atau orang lain melaksanakan tugas karena percaya bahwa pribadi pemimpinnya memiliki pengetahuan khusus dan keahlian serta mengetahui apa yang diperlukan oleh bawahannya, dan (e) referent power, bawahan melaksanakan

p.ISSN: $2407-800 X \quad$ e.ISSN: 2541-4356 
tugas karena kagum terhadap pribadi pemimpinnya, bah- kan bawahan ingin memperoleh restu, serta berke- inginan untuk bisa berbuat atau tampil seperti pribadi pemimpinnya. (Ekosiswoyo, 2007)

Menurut Aminah Kepala sekolah hendaknya 1 . mempertahankan kepemimpi nannya yang sudah berada pada taraf baik, sehingga guru tetap menjaga kestabilan disiplin kerjanya. 2. Tetap menjalin kerjasama dan komunikasi yang baik antara kepala sekolah dengan guru karena hal ini akan memberikan dampak positif bagi kemajuan lembaga pendidikan yang dikelolanya. 3. Sebagai calon pendidik dan pendidik, hendaknya lebih meningkatkan kesadaran akan pentingnya kedisiplinan, agar proses belajar mengajar berlangsung lebih efektif, terutama disiplin terhadap waktu. 4. Bagi penelitian selanjutnya, hasil penelitian ini dapat dijadikan bahan referensi untuk melakukan penelitian-penelitian selanjutnya, khususnya penelitian-penelitian yang berkenaan dengan kepemimpinan kepala sekolah dengan disiplin kerja guru. (Aminah, 2010)

\section{SIMPULAN}

Berdasarkan uraian tersebut di atas, maka dapat disimpulkan bahwa pemberian kepemimpinan kepala sekolah kerja guru dapat meningkatkan disiplin kerja guru dalam mengajar di sekolah. Data yang diperoleh menunjukkan bahwa setelah diadakan mengukur tingkat disiplin kerja guru melalui kepemimpinan kepala sekolah kerja yang lebih efisiensi, efektif, keadilan dan daya tanggap dengan penerapan siklus ini berpengaruh kepada kerja guru.

\section{DAFTAR RUJUKAN}

Aminah, s. (2010). Hubungan kepemimpinan kepala sekolah dengan disiplin kerja guru di smp dua mei ciputat skripsi. Skripsi.

Arief chaidir abdillah, f. W. (2011). Pengaruh kepemimpinan, stres kerja, disiplin kerja, dan kompensasi dengan kinerja pegawai. Daya saing jurnal ekonomi mananajemen sumber daya manusia, 12(1), 1-11.

Djatmiko, e. (2006). Dan sarana prasarana terhadap kinerja guru smp negeri kota semarang ( the effect of the principal ' $s$ leadership and facilities on the teacher' $s$ performance of state junior high schools of semarang municipality). Dokus ekonomi, 1(2), 19-30.

Eko triono. (2013). J urnal teknologi pendidikan $\mathrm{j}$ urnal teknologi pendidikan, 1(2), 226-238.

Ekosiswoyo, r. (2007). Kepemimpinan kepala sekolah yang efektif kunci pencapaian kualitas pendidikan. Jurnal ilmu pendidikan, 14(2), 76-82.

Rachmawati, y. (2013). Pengaruh kepemimpinan kepala sekolah terhadap kinerja guru. Jurnal pendidikan ekonomi, 01(01), 19-28.

Siti aminah. (2010). Hubungan kepemimpinan kepala sekolah dengan disiplin kerja guru di smp dua mei ciputat. 